\title{
Activity Improvement of Organophosphorus Hydrolase Enzyme by Error Prone PCR Method
}

\author{
Ehsan Rezaie ${ }^{1}$, Ali Mohammad Latifi ${ }^{*}$, Morteza Mirzaei ${ }^{2}$ \\ ${ }^{1}$ Molecular Biology Research Center, Systems Biology and Poisonings Institute, Baqiyatallah University of Medical Science, Tehran, \\ Iran \\ ${ }^{2}$ Applied Biotechnology Research Center, Baqiyatallah University of Medical Science, Tehran, Iran
}

Corresponding Author: Ali Mohammad Latifi, Associate Professor, Applied Biotechnology Research Center, Baqiyatallah University of Medical Science, Vanak Sq., Molasadra St., Tehran, Iran. Tel: +98 21 82482260, Fax: +98 21 82482260, Email: amlatifi290@ gmail.com

Received May 11, 2018; Accepted June 25, 2018; Online Published September 30, 2018

\begin{abstract}
Introduction: Organophosphorus compounds are frequently used as pesticides and insecticides in agriculture, livestock and home. Because of the high toxicity, it seems is very important its removal from the environment. An enzyme called organophosphorus hydrolase (OPH) is responsible for the decomposition of organophosphorus compounds in most of the strains. Production of enzymes and strains with more efficiency is frequently performed by genetic engineering techniques.

Materials and Methods: In this study, we used PCR-based method for quick and easy improvement in activity of OPH enzyme. We selected 5.5 $\mathrm{mM} \mathrm{Mg}^{2+}$ and $0.2 \mathrm{mM}$ and $\mathrm{Mn}^{2+}$ concentrations for high PCR product.

Results: After one round of error prone PCR (epPCR), The 5 number of screened strains (29\%) were shown more ability than the native strains to degrade of diazinon, with more than $25 \%$ raising ratio. The E6 strain was found to have highest improvement degradation, with $29.3 \%$ improvement. At 48-hour time point, the E6 strains were able to completely remove of diazinon.

Conclusions: The epPCR method has the low complexity than other methods and can provide a diverse library include efficient mutants.

Keywords: Error Prone PCR, OPH Enzyme, Organophosphorus Hydrolase, Improvement, Diazinon

Citation: Rezaie E, Latifi AM, Mirzaei M. Activity improvement of organophosphorus hydrolase enzyme by error prone PCR method. J Appl Biotechnol Rep. 2018;5(3):100-104. doi:10.29252/jabr.05.03.03.
\end{abstract}

\section{Introduction}

Pesticides are categorized into the most toxic substances that greatly diffuse in our environment and have high risks for humans and animals. Organophosphates (OPs) are one of the most harmful pesticides that are used in agriculture, household, gardens, domestic animals, sheep dips and even as chemical warfare. ${ }^{1,2}$ Malathion, parathion, diazinon, fenthion, dichlorvos, chlorpyrifos, soman, sarin, tabun, VX, tribufos are different types of OPs. ${ }^{3}$ These compounds can cause respiratory failure and death (at sufficient dosage) in vertebrates by phosphorylation of the acetylcholinesterase enzyme and loss of its function. ${ }^{1}$

Thus, the development of materials for bioremediation of OP compounds is essential. Some of the bacteria e.g. Flavobacterium sp., ${ }^{4}$ Pseudomonas sp., ${ }^{5,6}$ Agrobacterium radiobacter, Enterobacter sp. ${ }^{7-9}$ and also some of the bacterial enzymes include organophosphorus hydrolase (OPH), ${ }^{7}$ methyl parathion hydrolase $(\mathrm{MPH}),{ }^{10}$ organophosphorus acid anhydrolase (OPAA) $)^{11,12}$ are able to degrade one or more OP compounds.

So far, bioremediation of OPs has been studied. For example, in our pervious study, the mutants of $\mathrm{OPH}$ enzyme were designed, carrying disulfide bridges in their structure.
These mutants improved the thermostability of OPH enzyme but they showed no improvement in biodegradation activity. ${ }^{13}$ In order to create an environment for decontamination of OP compounds, the strains and their enzymes should own high and satisfactory biodegradation activity.

The directed evolution can offer superior properties to enzymes to improve their activity. Among different methods of directed evolution, the Site-directed mutagenesis of $\mathrm{OPH}^{7,14,15}$ and DNA shuffling ${ }^{15,16}$ were successfully applied to increase the enzyme efficiency.

In this study, we tried to gain recombinant $\mathrm{OPH}$ that is able to degrade diazinon (as its only carbon, phosphorus and energy source) more efficiently than native $\mathrm{OPH}$ by using error prone PCR method.

\section{Materials and Methods \\ Enzymes and Reagents}

Restriction endonucleases, dACTP, dTTP, dCTP, and dGTP were purchased from bioscience (Germany) and Genetbio (South Korea), respectively. $\mathrm{MgCl} 2$ and $\mathrm{MnCl} 2$ were obtained from Merck (Germany). T4 DNA ligase and Taq DNA polymerase were purchased from Fermentas to be used in PCR reaction Diazinon as the substrate was prepared by

Copyright (C) 2018 The Author(s). This is an open-access article distributed under the terms of the Creative Commons Attribution License (http:// creativecommons.org/licenses/by/4.0), which permits unrestricted use, distribution, and reproduction in any medium, provided the original work is properly cited. 
Sigma-Aldrich Co.

Strains, Culture Conditions and Plasmids

The recombinant expression strain pET-32a containing wild-type $\mathrm{OPH}$ (OPH-WT; pdb code, 1HZY) gene was purchased from Biomatik (Canada). The plasmid, pET-28a (+) (Novagen, Darmstadt, Germany) was used as cloning and expression vector. As cloning and expression host for recombinant plasmids $E$. coli $\mathrm{T} 7$ shuffled was selected. $E$. coli was grown overnight at $37^{\circ} \mathrm{C}$ on Luria-Bertani ${ }^{17,18}$ medium containing ampicillin $(100 \mathrm{mg} / \mathrm{mlL})$.

Mutagenesis by Error-Prone Polymerase Chain Reaction Random mutations were introduced to wild type oph gene by error-prone polymerase chain reaction (epPCR) method. The conditions for error-prone PCR were designed to create mutant libraries which include less and adequate change in DNA structure. Each $25 \mu \mathrm{L}$ error prone PCR mixture contained $40 \mathrm{ng}$ of $o p h$ gene as a template, $0.4 \mu \mathrm{M}$ each of the primer OPH-F (5' - ATAAGCTTTCTATCGGCACTGGTGA-3') and OPH-R (5'-TTCTCGAGGCTTGCACGCAGAGTC-3'), $5.5 \mathrm{mM} \mathrm{MgCl} 2,0.25 \mathrm{mM} \mathrm{MnCl} 2,0.2 \mathrm{mM}$ dGTP, $0.2 \mathrm{mM}$ dATP, $1 \mathrm{mM}$ dCTP, $1 \mathrm{mM}$ dTTP, 10× PCR buffer without $\mathrm{MgCl} 2$ and 5 units of Taq DNA polymerase. The error prone PCR was performed in 30 cycles, with initial denaturation temperature at $94^{\circ} \mathrm{C}$ for $5 \mathrm{~min}$, followed by 30 cycles of $94^{\circ} \mathrm{C}$ for 30 seconds, annealing step at 56C for 40 seconds, extending stage at $72^{\circ} \mathrm{C}$ for 1 minute, and final extension $72^{\circ} \mathrm{C}$ for 10 minutes. PCR was performed by thermocycler (Eppendorf, North America). The error prone PCR product was observed using agarose gel electrophoresis to determine molecular mass followed by purifying step using QIAquick PCR Purification Kit (Qiagen).

\section{Construction of Expression Library}

The purified epPCR product and pET-28a were digested by ZohI and HindIII. After digestion, the cleaved products were ligated by $\mathrm{T} 4$ ligase at $16^{\circ} \mathrm{C}$ overnight to construct plasmid owning mutant gene. The plasmids were cloned into T7 shuffled to assemble expression library. The cloned strains were cultured on LB agar containing kanamycin $(40 \mathrm{mg} / \mathrm{mL})$ at $37^{\circ} \mathrm{C}$ overnight. ${ }^{19}$

\section{Screening}

All of recombinant strains on LB agar were transferred into LB broth and incubated at $37^{\circ} \mathrm{C}$ overnight. Then, the recombinant strains $(100 \mu \mathrm{L})$ were inoculated into $5 \mathrm{~mL}$ fresh media until the OD at $600 \mathrm{~nm}$ was reached between 0.5-0.7. Clones were induced by $50 \mathrm{mM}$ IPTG and incubated for 4 hours at $37^{\circ} \mathrm{C}^{20}$ After centrifugation, precipitated bacterial cell were transferred on MSM agar $(0.1 \mathrm{~g} / \mathrm{L} \mathrm{NaCl}, 0.2 \mathrm{~g} / \mathrm{L}$ $\mathrm{KCl}, 0.5 \mathrm{~g} / \mathrm{L}$ (NH4)2SO4, $50 \mathrm{mg} / \mathrm{L} \mathrm{CaCl} 2 \cdot \mathrm{H} 2 \mathrm{O}, 15 \mathrm{~g} / \mathrm{L}$ agar) supplemented with 5,50 and $100 \mathrm{mg}$ of diazinon as only carbon, phosphorus and energy source and incubated for 4 days at $37^{\circ} \mathrm{C}$. The colonies on MSM agar were subcultured on LB agar and then 20 colonies were selected for assessment of whole cell activity.
Whole Cell Activity

The screened strains were cultured on MSM broth $(0.1 \mathrm{~g} / \mathrm{L}$ $\mathrm{NaCl}, 0.2$ g/L KCl, 0.5 g/L (NH4)2SO4, 50 mg/L CaCl2•H2O) supplemented with $50 \mathrm{mg}$ of diazinon as only carbon, phosphorus and energy source and then incubated for 48 hours at $37^{\circ} \mathrm{C}$. Degradation of diazinon (which is measured by concentration of diazinon) at $\mathrm{OD}=246 \mathrm{~nm}$ was assayed at 0, 24 and 48 hours by spectrophotometry (WSP, England).

\section{Results}

Optimization of $\mathrm{Mg} 2+$ and $\mathrm{Mn} 2+$ Concentration in the Error-Prone PCR System

As previously described by $\mathrm{Mao}$ et $\mathrm{al},{ }^{21}$ the high $\mathrm{Mg}^{2+}$ concentration causes the high PCR production with an intense strip but the low $\mathrm{Mg}^{2+}$ concentration, creates a poor PCR strip, even in the absence of $\mathrm{Mn}^{2+}$. Thus, we used 4 combinations of the $\mathrm{Mg}^{2+}$ and $\mathrm{Mn}^{2+}$ concentrations. The $\mathrm{Mg}^{2+}$ and $\mathrm{Mn}^{2+}$ combinations were included 3 and $0 \mathrm{mmol} / \mathrm{L}, 5$ and $0.1 \mathrm{mmol} / \mathrm{L}, 6$ and $0.25 \mathrm{mmol} / \mathrm{L}, 7$ and $0.4 \mathrm{mmol} / \mathrm{L}$ of $\mathrm{Mg}^{2+}$ and $\mathrm{Mn}^{2+}$, respectively. We observed that when the $\mathrm{Mg}^{2+}$ and $\mathrm{Mn}^{2+}$ combinations were 3 and $0 \mathrm{mmol} / \mathrm{L}, 5$ and $0.1 \mathrm{mmol} / \mathrm{L}, 6$ and $0.25 \mathrm{mmol} / \mathrm{L}$ respectively, the PCR product was relatively high but when the $\mathrm{Mg}^{2+}$ and $\mathrm{Mn}^{2+}$ combinations were 7 and $0.4 \mathrm{mmol} / \mathrm{L}$ respectively, the PCR product was low (Figure 1). Finally, we selected the 5.5 and $0.2 \mathrm{mmol} / \mathrm{L}$ of the $\mathrm{Mg}^{2+}$ and $\mathrm{Mn}^{2+}$ combination, respectively.

\section{Screening of the Mutant Library}

The derived mutant library of epPCR process was cultured on MSM agar supplemented with 5, 50 and $100 \mathrm{mg}$ of diazinon. The mutant colonies were obtained in all of concentrations of diazinon but the E. coli T7 shuffled without oph gene was not able to grow in any of concentration of diazinon. Due to the small size of the mutant colonies, work continued with, 20

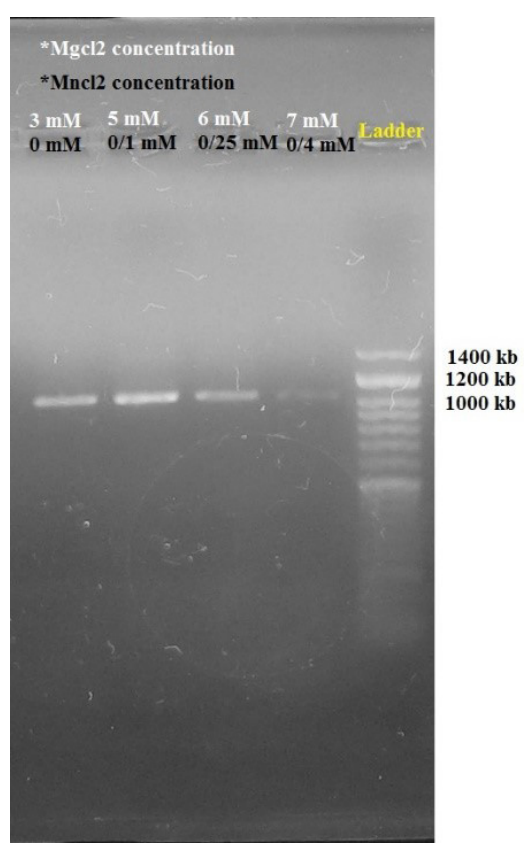

Figure 1. The epPCR Product of oph Gene on 1\% Agarose Gel. The $\mathrm{Mg}^{2+}$ and $\mathrm{Mn}^{2+}$ combinations are shown. 
selected colonies from LB agar.

\section{Whole Cell Activity}

As shown in Figure 2 and Figure 3, at 24 hours, 15 of screened strains ( $71 \%$ of the total) showed elevated degradation ability than the native strains (T7 shuffled strains containing wildtype OPH in pET32). Six screened strains (29\%) showed less ability than the native strains in degradation of diazinon. The E6, E9, E15, E16 and E20 screened strains were characterized as the strains which possess highest improvement in degradation ability, with more than $25 \%$ increased efficiency (Figure 4). The E6 strain was found to have highest improvement of degradation, with $29.3 \%$ ratio. At 48 hours, the E6 strain had the superiority over the native strain in removing diazinon completely. (Figure 5).

\section{Discussion}

Oph gene has been manipulated by numerous different rational and directional methods for stability $(\mathrm{pH}$ and thermal) or activity improvement, broading the substrate range, decreasing degradation time and offering the ability of degrading in high concentrations of OPs. In this study, for the first time, we applied error prone PCR method to create mutated $E$. coli strains with improved oph enzyme activity. In previous studies, error prone PCR method have been applied due to its simplicity, cost-effective, efficient and production of high similar genes for shuffling, by researcher in order to improve the features of proteins. $22-26$

We succeeded to optimize the amount of $\mathrm{Mg}^{2+}$ and $\mathrm{Mn}^{2+}$ concentrations for epPCR amplification of oph gene. We selected 5.5 and $0.2 \mathrm{mM}$ from $\mathrm{Mg}^{2+}$ and $\mathrm{Mn}^{2+}$ respectively, for high throughput PCR product. In this situation, the amount of

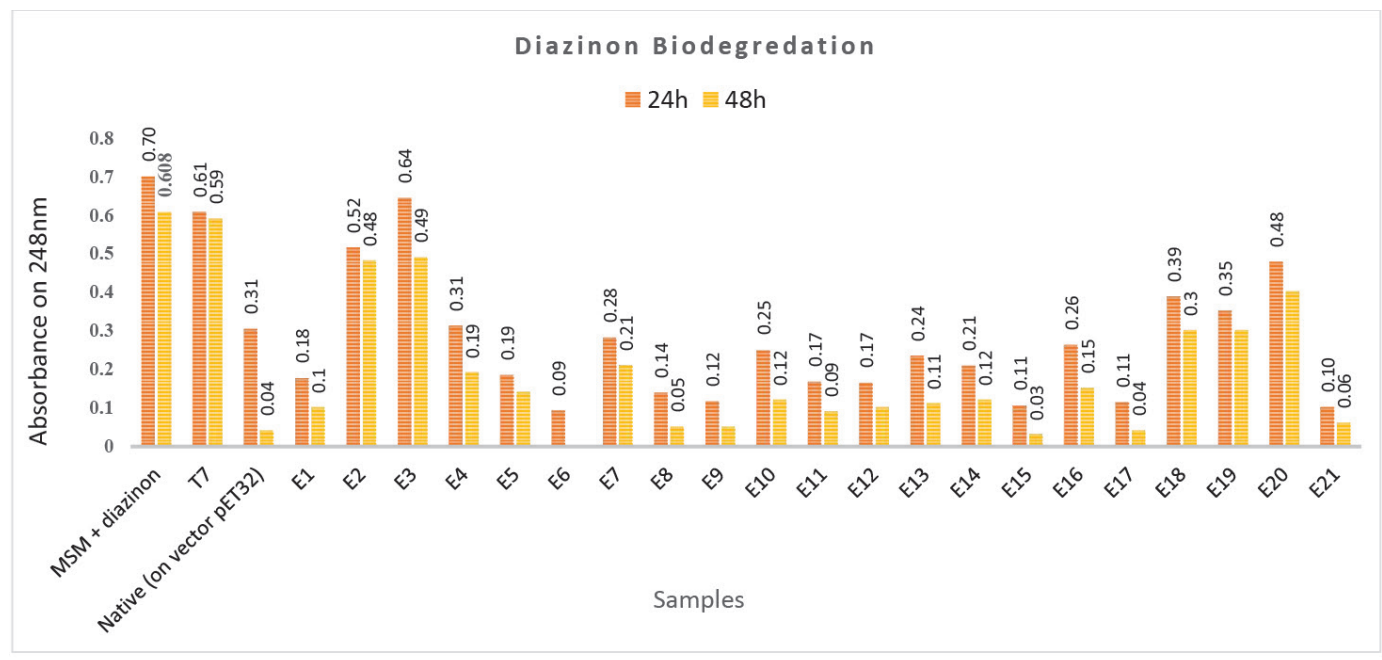

Figure 2. Comparison of Diazinon Biodegradation in Control and Mutant Strains. The level of diazinon biodegradation in $5 \mathrm{~mL}$ of MSM agar supplemented with $50 \mathrm{mg} / \mathrm{L}$ diazinon for all samples in two time points (24 and 48 hours) was observed. Absorbance was measured at $248 \mathrm{~nm}$. MSM + diazinon was evaluated for definition of spontaneously degradation; T7: E. coli T7 shuffled strain with no vector and oph gene; Native: E. coli T7 shuffled with parent oph gene along with vector pET32; E1 to E21: E. coli T7 shuffled with mutant oph gene including vector pET28.

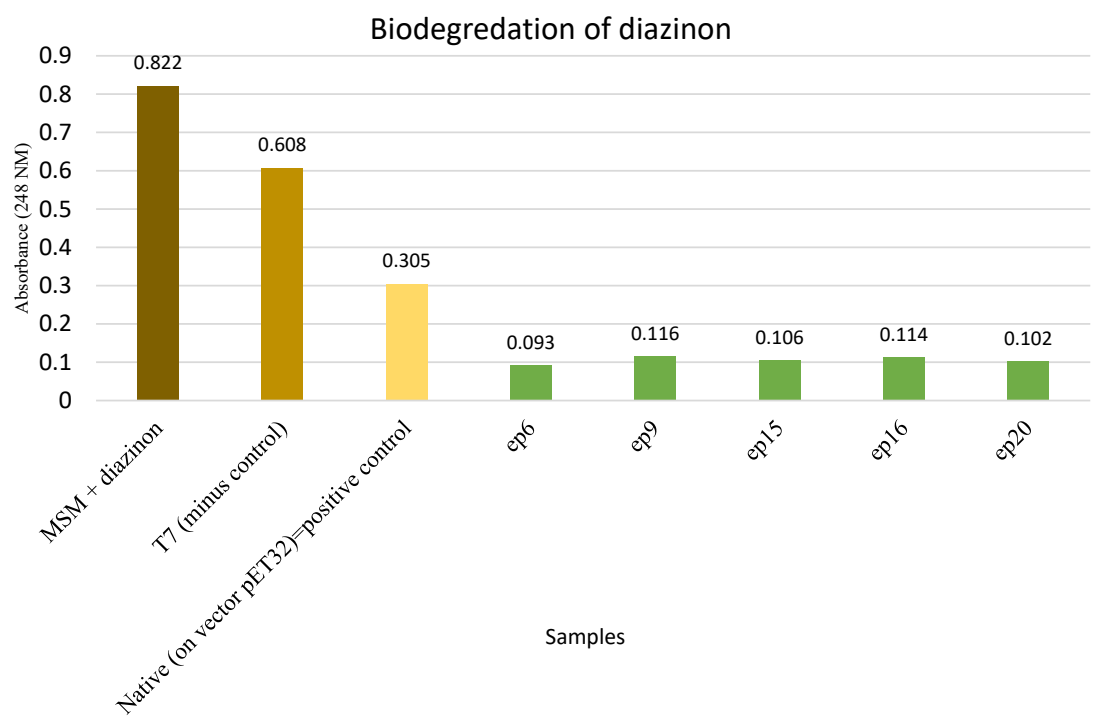

Figure 3. Biodegradation of Diazinon. The 5 preferable mutants, capable of degrading diazinon more efficiently than other strains. 


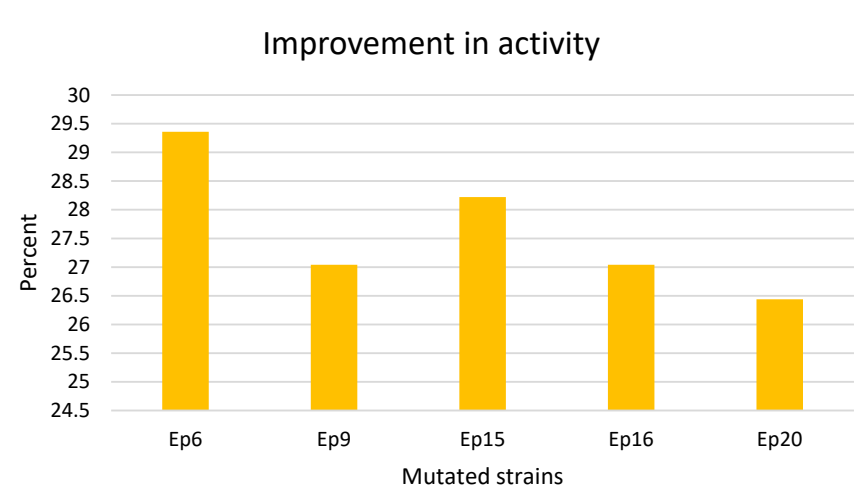

Figure 4. Rising Ratio of E6, E9, E15, E16 and E20 in Biodegradation of Diazinon.

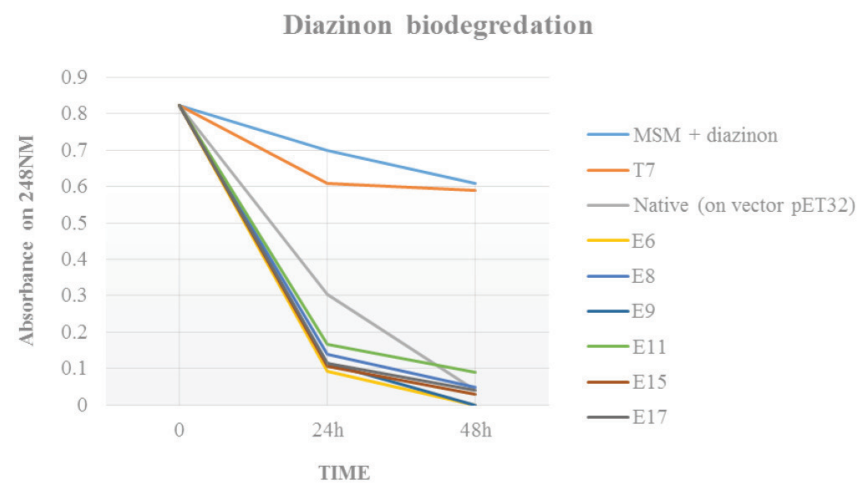

Figure 5. Diazinon Biodegradation at 0,24 and 48 Hours Intervals. The E6 mutant was able to remove diazinon completely after $48 \mathrm{~h}$.

PCR product is high and (based on previous study) mutation rate is probably suitable for creating a large and functional library. ${ }^{17,21,27}$ When $\mathrm{Mg}^{2+}$ and $\mathrm{Mn}^{2+}$ concentrations is higher than 6 and $2.5 \mathrm{mM}$ respectively, epPCR product is very low and on the other hand when $\mathrm{Mg}^{2+}$ and $\mathrm{Mn}^{2+}$ concentrations is lower than 5 and $0.1 \mathrm{mM}$ respectively, epPCR product is high but probably mutation rate is very low. Indeed, error rate of Taq DNA polymerase has a significant correlation with content of $\mathrm{Mg}^{2+}$ and $\mathrm{Mn}^{2+}$ in epPCR reaction. ${ }^{28}$ In previous study by Mao and colleagues, the concentrations of $\mathrm{Mg}^{2+}$ and $\mathrm{Mn}^{2+}$ for high PCR product and suitable mutated frequency was obtained 3 and $0.4 \mathrm{mM}$ for $\mathrm{Mg}^{2+}$ and $\mathrm{Mn}^{2+}$, respectively ${ }^{21}$ which is comparable with our study. It should be noted that high $\mathrm{Mg}^{2+}$ and $\mathrm{Mn}^{2+}$ concentrations will cause high error rate and finally produce more unique sequences. ${ }^{29}$

In our previous study by rational design of oph gene, multiple mutants was designed and evaluated. Some of mutants were improved in terms of thermostability (by introducing disulfide bridge) but we observed no improvement in activity. ${ }^{13}$ It seems, fewer changes are observed in the rational studies and also less number of functional mutants was achieved.

In our study, $73 \%$ of screened strains were capable to degrade diazinon more efficiently compared to native strain. The E6 strain was determined as the most potential strain in biodegradation with $29.3 \%$ raising ratio which is comparable with a study by Mao on beta-1,3-1,4-glucanase from Bacillus altitudinis $^{21}$ that resulted in improved activity by $48.6 \%$, and also the study by Liao for Recombinant phyA Mutant Phytase from Aspergillus niger N25 that showed 29\% improvement. ${ }^{30}$

However, in a study by Loo on Epoxide Hydrolase from $A$. radiobacter using error-prone PCR and DNA shuffling, the mutants gained up to 13-fold improved enantioselectivity toward pNPGE and at least three other epoxides. ${ }^{17}$ In the study by Zuo on serine hydroxyl methyl transferase gene from Escherichia coli strain AB90054 using DNA shuffling method, a mutant namely $3 \mathrm{E} 7$ showed 8-fold increase in enzyme activity and 41-fold increase in enzyme productivity compared with its wild-type parent. ${ }^{31}$ This is due to introducing so many changes and recombination in target gene but in many cases, success is not achieved using recombination methods such as DNA shuffling, SHIPREC, SCRATCHY or other similar methods

In this study, we observed that the ep6 mutant was able to completely degrade diazinon after $48 \mathrm{~h}$. It can be concluded that obtained mutations have made changes in enzyme expressing gene that is responsible for both activity and stability improvement. However, in order to prove that further investigation is needed.

As the enzyme was expressed in the cytoplasm of the E. coli host and it is not plasma-membrane bound or secreted form in this host, the screening is associated with many problems. Due to encountered difficulties, in further studies it is suggested that the oph gene should be expressed in secretory host for example B. subtilis or in the form of plasma-membrane bound in yeast or E. coli.

\section{Conclusions}

We obtained the mutants of oph gene that are able to express $\mathrm{OPH}$ enzymes with profound activity; therefore we recommend the error PCR methods as a rapid method for improvement of the protein properties. The epPCR method has low complexity in comparison with other common methods and can provide a diverse library including efficient mutants.

\section{Authors' Contributions}

RE conceived and planned the experiments and also performed the experimental analysis, LAM and MM were involved in planning and processing the experimental data, LAM was supervised the work, RE drafted the manuscript. All authors discussed the results and commented on the manuscript.

\section{Conflict of Interest Disclosures}

The authors declare they have no conflicts of interest.

\section{References}

1. Priyadharshini UK, Latha R, Kavitha $U$, Nirmala N. Effects of Organophosphorus Pesticides on Cardiorespiratory Parameters among the Farmers. J Clin Diagn Res. 2017;11(9):Cc01-cc04. doi:10.7860/jcdr/2017/26724.10590.

2. Martin-Reina J, Duarte JA, Cerrillos L, Bautista JD, Moreno I. Insecticide reproductive toxicity profile: organophosphate, carbamate and pyrethroids. J Toxins. 2017;4(1):1-7.

3. Costa LG. Organophosphorus Compounds at 80: Some Old and New Issues. Toxicol Sci. 2018;162(1):24-35. doi:10.1093/toxsci/ $\mathrm{kf} \times 266$.

4. Singh BK. Organophosphorus-degrading bacteria: ecology and industrial applications. Nat Rev Microbiol. 2009;7(2):156-164. 
doi:10.1038/nrmicro2050.

5. Serdar CM, Gibson DT, Munnecke DM, Lancaster JH. Plasmid Involvement in Parathion Hydrolysis by Pseudomonas diminuta. Appl Environ Microbiol. 1982;44(1):246-249.

6. Walker AW, Keasling JD. Metabolic engineering of Pseudomonas putida for the utilization of parathion as a carbon and energy source. Biotechnol Bioeng. 2002;78(7):715-721. doi:10.1002/ bit.10251.

7. Horne I, Sutherland TD, Harcourt RL, Russell RJ, Oakeshott JG. Identification of an opd (organophosphate degradation) gene in an Agrobacterium isolate. Appl Environ Microbiol. 2002;68(7):33713376. doi:10.1128/aem.68.7.3371-3376.2002.

8. Siddavattam D, Khajamohiddin S, Manavathi B, Pakala SB, Merrick M. Transposon-like organization of the plasmid-borne organophosphate degradation (opd) gene cluster found in Flavobacterium sp. Appl Environ Microbiol. 2003;69(5):25332539. doi:10.1128/aem.69.5.2533-2539.2003.

9. Singh BK, Walker A, Morgan JA, Wright DJ. Effects of soil pH on the biodegradation of chlorpyrifos and isolation of a chlorpyrifosdegrading bacterium. Appl Environ Microbiol. 2003;69(9):51985206. doi:10.1128/aem.69.9.5198-5206.2003.

10. Dong YJ, Bartlam M, Sun L, et al. Crystal structure of methyl parathion hydrolase from Pseudomonas sp. WBC-3. J Mol Biol. 2005;353(3):655-663. doi:10.1016/j.jmb.2005.08.057.

11. Cheng TC, DeFrank JJ, Rastogi VK. Alteromonas prolidase for organophosphorus G-agent decontamination. Chem Biol Interact. 1999;119-120:455-462. doi:10.1016/S0009-2797(99)00058-7.

12. Cheng TC, Harvey SP, Stroup AN. Purification and Properties of a Highly Active Organophosphorus Acid Anhydrolase from Alteromonas undina. Appl Environ Microbiol. 1993;59(9):31383140 .

13. Farnoosh G, Khajeh K, Latifi AM, Aghamollaei H. Engineering and introduction of de novo disulphide bridges in organophosphorus hydrolase enzyme for thermostability improvement. J Biosci. 2016;41(4):577-588. doi:10.1007/s12038-016-9643-8.

14. Cho CM, Mulchandani A, Chen W. Bacterial cell surface display of organophosphorus hydrolase for selective screening of improved hydrolysis of organophosphate nerve agents. Appl Environ Microbiol. 2002;68(4):2026-2030. doi:10.1128/AEM.68.4.20262030.2002.

15. Singh BK, Walker A. Microbial degradation of organophosphorus compounds. FEMS Microbiol Rev. 2006;30(3):428-471. doi:10.1111/j.1574-6976.2006.00018.x.

16. Yang H, Carr PD, McLoughlin SY, et al. Evolution of an organophosphate-degrading enzyme: a comparison of natural and directed evolution. Protein Eng. 2003;16(2):135-145. doi:10.1093/ proeng/gzg013.

17. van Loo B, Spelberg JH, Kingma J, Sonke T, Wubbolts MG, Janssen DB. Directed evolution of epoxide hydrolase from A. radiobacter toward higher enantioselectivity by error-prone PCR and DNA shuffling. Chem Biol. 2004;11(7):981-990. doi:10.1016/j. chembiol.2004.04.019.

18. Keshtvarz M, Salimian J, Yaseri M, et al. Bioinformatic prediction and experimental validation of a PE38-based recombinant immunotoxin targeting the Fn14 receptor in cancer cells. Immunotherapy. 2017;9(5):387-400. doi:10.2217/imt-2017-0008.

19. Rezaee E, Miri E, Salimian J, Olad G, et al. Survey and comparison of immunization scale of the recombinant proteins of attachment subunit of tetanus and botulinom (A) toxins. Journal of Ilam University of Medical Sciences. 2013;21(5):109-114. [Persian].

20. Rezaee E, Saadati M, Salimian J, et al. Evaluating and Comparing Immunization Level of the Recombinant Proteins, Binding Domain of Tetanus Neurotoxin and B Subnnit of Heat Labile Toxin of Escherichia coli, and their Relation to Immunological Memory. Journal of Ilam University of Medical Sciences. 2014;21(7):266273.

21. Mao S, Gao P, Lu Z, et al. Engineering of a thermostable beta1,3-1,4-glucanase from Bacillus altitudinis YC-9 to improve its catalytic efficiency. J Sci Food Agric. 2016;96(1):109-115. doi:10.1002/jsfa.7066.

22. Cui B, Zhang L, Song $Y$, et al. Engineering an enhanced, thermostable, monomeric bacterial luciferase gene as a reporter in plant protoplasts. PLoS One. 2014;9(10):e107885. doi:10.1371/ journal.pone.0107885.

23. Nakaniwa T, Tada T, Takao M, Sakai T, Nishimura K. An in vitro evaluation of a thermostable pectate lyase by using error-prone PCR. J Mol Catal B Enzym. 2004;27(2):127-131. doi:10.1016/j. molcatb.2003.10.005.

24. Pritchard L, Corne D, Kell D, Rowland J, Winson M. A general model of error-prone PCR. J Theor Biol. 2005;234(4):497-509. doi:10.1016/j.jtbi.2004.12.005.

25. Yang J, Ruff AJ, Arlt M, Schwaneberg U. Casting epPCR (cepPCR): A simple random mutagenesis method to generate high quality mutant libraries. Biotechnol Bioeng. 2017;114(9):1921-1927. doi:10.1002/bit.26327.

26. Minamoto T. Random Mutagenesis by Error-Prone Polymerase Chain Reaction Using a Heavy Water Solvent. Methods Mol Biol. 2017;1498:491-495. doi:10.1007/978-1-4939-6472-7_33.

27. Rasila TS, Pajunen MI, Savilahti H. Critical evaluation of random mutagenesis by error-prone polymerase chain reaction protocols, Escherichia coli mutator strain, and hydroxylamine treatment. Anal Biochem. 2009;388(1):71-80. doi:10.1016/j.ab.2009.02.008.

28. Cadwell RC, Joyce GF. Randomization of genes by PCR mutagenesis. PCR Methods Appl. 1992;2(1):28-33. doi:10.1101/ gr.2.1.28.

29. Drummond DA, Iverson BL, Georgiou G, Arnold FH. Why higherror-rate random mutagenesis libraries are enriched in functional and improved proteins. J Mol Biol. 2005;350(4):806-816. doi:10.1016/j.jmb.2005.05.023.

30. Liao $\mathrm{Y}$, Zeng $\mathrm{M}, \mathrm{Wu} Z \mathrm{ZF}$, et al. Improving phytase enzyme activity in a recombinant phyA mutant phytase from Aspergillus niger N25 by error-prone PCR. Appl Biochem Biotechnol. 2012;166(3):549562. doi:10.1007/s12010-011-9447-0.

31. Zuo ZY, Zheng ZL, Liu ZG, Yi QM, Zou GL. Cloning, DNA shuffling and expression of serine hydroxymethyltransferase gene from Escherichia coli strain AB90054. Enzyme and Microbial Technology. 2007;40(4):569-577. doi:10.1016/j. enzmictec.2006.05.018. 